\title{
MOLECULAR CHARACTERIZATION OF ISOLATED DOMINANT YEAST STRAINS DURING ETHANOL FERMENTATION PROCESS
}

Nádia Cristina Viana ${ }^{1}$, Daniela Defavari do Nascimento ${ }^{2},{\text { Marcos } \operatorname{Prada}^{2} \text {, Sandra Helena da Cruz }}^{1}$

${ }^{1}$ University of São Paulo - ESALQ/USP, E-mail: nadiaviana@usp.br, shcruz@usp.br

${ }^{2}$ Technology College of São Paulo - FATEC/Piracicaba, E-mail: daniela.nascimento01@fatec.sp.gov.br, adarp2001@yahoo.com.br

\section{ABSTRACT}

The Brazilian fermentation process has unique characteristics, such as the utilization of acid yeast cell recycling. The difficulty to sterilize large volumes of water and sugarcane juice enables the presence of indigenous yeasts. Occasionally, those yeast strains are better adapted and exert dominance over the commercial strains employed in the fermentation process. This study explored the prevalence of indigenous yeast strains in an ethanol producing unit in Brazil. The samples, ranging from beginning to late stages of the harvest season, show the presence of indigenous yeast. This can be observed by the divergence in PCR banding patterns from the samples, when compared to the commercial yeast strain PE-2 utilized by this particular ethanol producing unit. The results obtained point to the dominance of indigenous yeasts in the fermentation system that surpass in occurrence the commercial strain in all stages of the harvest season.

Keywords: Isolation, yeast diversity, indigenous yeast, Saccharomyces cerevisiae

\section{CARACTERIZAÇÃO MOLECULAR DE LINHAGENS DE LEVEDURAS DOMINANTES ISOLADAS DURANTE PROCESSO FERMENTATIVO PARA PRODUÇÃO DE ETANOL}

\section{RESUMO}

O processo de fermentação brasileiro possui características únicas, como a utilização do reciclo das células de levedura. A dificuldade de esterilizar grandes volumes de água e caldo de cana-de-açúcar permite a presença de leveduras nativas. Ocasionalmente, essas linhagens de leveduras são melhor adaptadas e exercem dominância sobre as linhagens comerciais empregadas no processo de fermentação. Este estudo explorou a prevalência de linhagens de leveduras nativas em uma unidade produtora de etanol no Brasil. As amostras, desde o início até o final da safra, mostram a presença de leveduras nativas. Isto pode ser observado pela divergência nos padrões de 
bandas de PCR das amostras, quando comparadas à linhagem comercial PE-2 utilizada por essa unidade produtora de etanol em particular. Os resultados obtidos apontam para a predominância de leveduras nativas no processo de fermentação, que superam a dominância da linhagem comercial em todas as etapas da safra.

Palavras-chave: Isolamento, diversidade de leveduras, leveduras nativas, Saccharomyces cerevisiae

\section{INTRODUCTION}

Brazil is the largest producer of ethanol derived from sugarcane and the first to implement it as an alternative to fossil fuels, and its share of consumption of renewable energy is at the level of $42 \%$. Due to this, Brazil is a world leader in RES (renewable energy sources) utilization (AMORIM et al. 2011; MĄCZYŃSKA et al., 2019). The use of sugarcane to produce sugar and ethanol, with co-generation of renewable energy from surplus bagasse, is considered a model of sustainable energy generation. This is driven by the demand for decreased fossil energy use (DELLA-BIANCA \& GOMBERT, 2013).

The Brazilian industrial alcoholic fermentation mainly utilizes the Melle-Boinot process, in which the yeast cells used in the fermentation are separated from the fermented must by centrifugation. The must is then sent to the distillation processes; while the cells are subjected to acid wash treatment and then on to a new fermentative cycle (AMORIM et al., 2011).

Several factors may affect the fermentation yield, especially microbial contamination, either by bacteria or native yeasts strains, the so-called wild yeasts, whether these are Saccharomyces or not. Wild yeasts are mostly native to the environment, being introduced in the fermentation process along with substrates. They can cause excessive foaming and flocculation, leading to a decrease in ethanol production and fermentative efficiency. This damage is proportional to the level of contamination present, and modifications in the morphology of Saccharomyces cerevisiae yeast may exacerbate these undesirable traits (STEENSELS \& VERSTREPEN, 2014).

However, the yeast strains found in the microbiota of industrial fermentations are not always a cause of contamination and damage in the process. Many of the strains found in the industrial environment are good examples of microorganisms with desirable characteristics for use on industrial scale, being resistant to stressors such as high concentrations of ethanol and osmotic 
stress, and these strains can become candidates for selection processes to meet the demands for more efficient microorganisms (REIS et al., 2018; 2013). These native strains are highly adaptive and compete with the commercial strains used by the ethanol producing units, surviving throughout the fermentative cycles, despite the acid wash treatment (VIANA et al., 2017).

Although selection of native strains that are deemed good fermenters is often successful, this process is overly laborious and time-consuming. Wild yeasts that fit the profile desired for selection processes exhibit high fermentative efficiency combined with the ability to tolerate stressors; also, the strains need to exhibit the ability to exert dominance over invasive yeast strains throughout the process (BASSO et al., 2008). Yeast strains with flocculant behavior are avoided for ethanol production, as they tend to diminish the fermentation yield (RUYTERS et al., 2015).

Understanding the occurrence of dominant indigenous strains is substantial to unravel the interactions between them and commercial strains, enabling the possible strains with profiles suitable to be employed as starter cultures, being these strains fit to endure the Brazilian fermentation process. The goal of this study was to monitor through molecular characterization the presence and dominance of indigenous; the so-called "wild" yeasts; over the commercial strains during the fermentation process. This particular bioethanol plant utilizes the commercial yeast strain PE-2 as their starter culture, and its predominance during the process was also monitored.

\section{MATERIAL AND METHODS}

\section{Yeast sampling and identification}

Samples of leavened wine were directly collected from active fermentation during the 2013 to 2014 harvest season from a bioethanol plant in Piracicaba, State of São Paulo, Brazil. The samples were serially diluted $\left(10^{-3}, 10^{-4}\right)$ in saline solution $(0.85 \%$, w/v) in order to obtain isolated colonies, of which $300 \mu \mathrm{L}$ were aseptically inoculated in a Petri dish containing YPD medium (10 g.L - $^{-1}$ yeast extract; 10 g.L -1 $^{-1}$ peptone; 20 g.L -1 $^{-1}$ glucose) plus chloramphenicol (100 $\left.\mu \mathrm{g} . \mathrm{L}^{-1}\right)$ and tetracycline $\left(100 \mu \mathrm{g} . \mathrm{L}^{-1}\right)$. Inoculated plates were incubated at $30^{\circ} \mathrm{C}$ for 48 hours.

Four separate samples originated 24 isolated colonies, 6 colonies from each sample, all randomly selected. All samples were collected from the same fermentation vessel. The sampling dates and colony identification are shown in Table 1. 
After the initial selection, the 24 randomly selected colonies were streaked into Petri dishes containing YPD medium. Yeast samples were grown in liquid YPD medium in order to obtain a sufficient cell mass for DNA extraction.

Table 1. Sample dates and identification of the obtained yeast colonies, sampled from an ethanol producing unit in Brazil, starting in May 2013 to October 2013.

\begin{tabular}{c|c|c}
\hline Sampling Dates & Fermentation process period & Colony identification \\
\hline $03 / 05 / 2013$ & Beginning & A1 to A6 \\
\hline $28 / 05 / 2013$ & Beginning & B1 to B6 \\
\hline $29 / 06 / 2013$ & Mid-season & C1 to C6 \\
\hline $10 / 10 / 2013$ & Final & D1 to D6 \\
\hline
\end{tabular}

\section{DNA Extraction}

Total genomic DNA was extracted from the yeast precipitate applying the CTAB (Cetyl trimethylammonium bromide) adapted method (DOYLE \& DOYLE, 1987). DNA from fresh cells was extracted as follows: fresh cells from selected colonies were individually transferred to sterilized tubes containing $10 \mathrm{~mL}$ of liquid YPD medium, and incubated in a shaker (Cientec, CT712) for 24 hours. Approximately $1.5 \mathrm{~mL}$ of samples were transferred to $2.0 \mathrm{~mL}$ Eppendorf tubes and centrifuged (Hettich Rotina 420R) at 5,000 $g$ for 5 minutes, discarding the supernatant and keeping the precipitated yeast cells.

Then, $700 \mu \mathrm{L}$ of extraction buffer free of $\beta$-mercaptoethanol and Proteinase $\mathrm{K}(1.4 \mathrm{M} \mathrm{NaCl}$, $100 \mathrm{mM}$ Tris $\mathrm{HCl} \mathrm{pH}=8 ; 20 \mathrm{mM}$ EDTA $\mathrm{pH}=8 ; 1 \%$ PVP; $2 \%$ CTAB, previously heated to $60^{\circ} \mathrm{C}$, were added to the samples. The samples were agitated and heated at $60^{\circ} \mathrm{C}$ for 20 minutes, with homogenization at 5 minutes intervals. The samples were then allowed to cool to room temperature for 5 minutes, followed by the addition of $600 \mu \mathrm{L} 24: 1$ CIA (chloroform:isoamyl alcohol). Homogenization was done by inverting the tubes (25 times) until an emulsion was formed, prior to centrifugation $(14,000 \mathrm{~g})$ at room temperature for 7 minutes.

The aqueous upper phase was transferred to a new Eppendorf tube. Then, $200 \mu \mathrm{L}$ of extraction buffer and $600 \mu \mathrm{L}$ of CIA were added. After homogenization, the samples were centrifuged $(14,000 \mathrm{~g})$ at room temperature for 7 minutes. The upper aqueous phase was again transferred to fresh tube, repeating this step once more. 
After centrifugation, the upper aqueous phase containing the genomic DNA, was recovered. Precipitation was done by the addition of $600 \mu \mathrm{L}$ of isopropanol; homogenization was done by inverting the tubes for 1 minute, followed by centrifugation $(14,000 \mathrm{~g})$ at $4^{\circ} \mathrm{C}$ for 15 minutes. The supernatant was then discarded and the precipitate washed with $600 \mu \mathrm{L}$ of $70 \%$ ethanol, kept at $20^{\circ} \mathrm{C}$ for 20 minutes, prior to centrifugation for 15 minutes at $4^{\circ} \mathrm{C}$, at $14,000 \mathrm{~g}$. After drying, the precipitate was suspended in $30 \mu \mathrm{l}$ of TE buffer $(10 \mathrm{mM}$ Tris, $1 \mathrm{mM}$ EDTA, $\mathrm{pH}=7.5)$ containing $10 \mu \mathrm{g} \cdot \mathrm{mL}^{-1} \mathrm{RNAse}$, and maintained at $37^{\circ} \mathrm{C}$ for 1 hour before being stored at $4{ }^{\circ} \mathrm{C}$.

\section{Molecular Characterization}

Verification of total DNA quality and quantification was performed by agarose gel electrophoresis $(1 \%)$. The band profiles were visualized through staining with ethidium bromide (0.01 ng.mL-1) under ultraviolet light (Gel Logic 212 Pro) (SAMBROOKE et al., 1989).

The PCR (Polymerase Chain Reaction) reaction of the samples' genomic DNA utilized two specific pairs of primers for molecular characterization of yeast strains (CARVALHO-NETTO et al., 2013). A final volume of $20 \mu \mathrm{L}$ was utilized for the PCR reaction, using Dream Taq® (Fermentas) according to manufacturer's recommendations.

Amplification of the DNA segment was performed in two different programs in the thermocycler (TECHNE, TC-4000), due to differences in the annealing temperature of the primer pairs utilizing Program 1 (primers P1 (TGTCGCCTCATCTAAAGCAA) and P2 $\begin{array}{llllll}\text { (TGTAATtTGGGATGCAGCAG)) } & \text { and } & \text { Program } & 2 & \text { (primers }\end{array}$ (ACGATTCCAAATACGACGAA) and P4 (TTCTGTTTCGCTTCTGAATTG)), both sets of primers are Saccharomyces cerevisiae-specific, based on the identification of large length polymorphisms. The Program 1 used initial denaturation $\left(94^{\circ} \mathrm{C}\right.$ for $\left.5 \mathrm{~min}\right)$, the reaction mixture was submitted to 45 cycles at $94^{\circ} \mathrm{C}$ for 45 seconds, $54^{\circ} \mathrm{C}$ for 40 seconds and at $72^{\circ} \mathrm{C}$ for 1.5 minutes with a final extension at $72^{\circ} \mathrm{C}$ for $2 \mathrm{~min}$. For the Program 2 the annealing temperature was changed, thus: $94^{\circ} \mathrm{C}$ for $5 \mathrm{~min}, 45$ cycles of $94^{\circ} \mathrm{C}$ for $45 \mathrm{~s}, 57^{\circ} \mathrm{C}$ for $40 \mathrm{~s}$ and $72^{\circ} \mathrm{C}$ for $1.5 \mathrm{~min}$; plus $72^{\circ} \mathrm{C}$ for 2 min final extension (CARVALHO-NETTO et al., 2013).

The choice of primers comes from a study (CARVALHO-NETTO et al., 2013) that proposes a simple and effective PCR-based method to monitor the yeast population in alcoholic fermentation. The genome of $S$. cerevisiae contains regions of repetitive DNA sequences, such as the delta regions, and the positioning and number of these regions has intraspecific patterns that 
can be used to differentiate and identify yeast species isolated from the fermentation process, or the local microbiota (XUFRE et al., 2011).

The PCR product ( $10 \mu \mathrm{L}$ of each reaction) was submitted to $1 \%$ agarose gel electrophoresis with $0.5 \mathrm{x}$ TBE buffer, submitted to $75 \mathrm{~V}$ current for 60 minutes, with a $1 \mathrm{~kb}$ molecular marker (DNA Ladder, Fermentas), plus sample buffer (Dye IV) (SAMBROOKE et al., 1989). Band profiles were visualized by staining with ethidium bromide (0.01ng. $\mu \mathrm{L}-1)$ under UV light.

\section{RESULTS AND DISCUSSION}

The PCR technique employed to analyze genomic DNA from the yeast samples revealed distinct banding patterns between the analyzed samples, and concomitantly between the two assays using different pairs of primers.

Analyzing the differences in banding patterns obtained and comparing them with the banding patterns exhibited by the PE-2 commercial strain, the dissimilarity between them suggest the presence of indigenous yeasts. One of the selected strains appears to be more dominant and better adapted to persist throughout the sugarcane harvest season, which has been established since the first sample (from 5/3/2013). Another less resistant yeast strain can be observed, but only in the initial samples, belonging to the beginning of the sugarcane harvest.

The PE-2 strain was introduced into the process on 04/04/2013. This commercial strain was not able to establish dominance in the presence of more adapted indigenous yeasts found in this bioethanol plant, being easily replaced, as observed in the diverging banding patterns (Figure 1 and 2). It is evident throughout the sampling period, from May to October, that none of the yeast strains identified had the banding pattern compatible to PE-2, but both indigenous strains were able to carry out the fermentation process without damages and presence of obvious signs of contamination.

Contamination during fermentation can be caused by bacteria such as Lactobacillus, Acetobacter and Zymomonas, among others, and indigenous yeasts, that can range from Saccharomyces cerevisiae to non-Saccharomyces yeasts. The undesirable features in fermentation are decreased process yield, reduced yeast cell viability, production of excessive foam, biofilm formation and reduced metabolization of the sugar available in the must, most of them caused by dominant indigenous yeast strains (BONATELLI et al., 2019). 
The product of PCR reaction utilizing the pair of primers $\mathrm{P} 1$ and $\mathrm{P} 2$ at $54^{\circ} \mathrm{C}$ for the samples of 05/03/2013 and 05/28/2013 are shown in Figure 1a. The banding patterns obtained allow the visualization of the indigenous yeasts when compared to the banding pattern displayed by commercial strain PE-2. The same divergence of banding patterns can be observed in the samples from 06/29/2013 and 10/10/2013, analyzed under the same conditions, where two main banding patterns, different from PE-2, can be observed (Figure 1b)
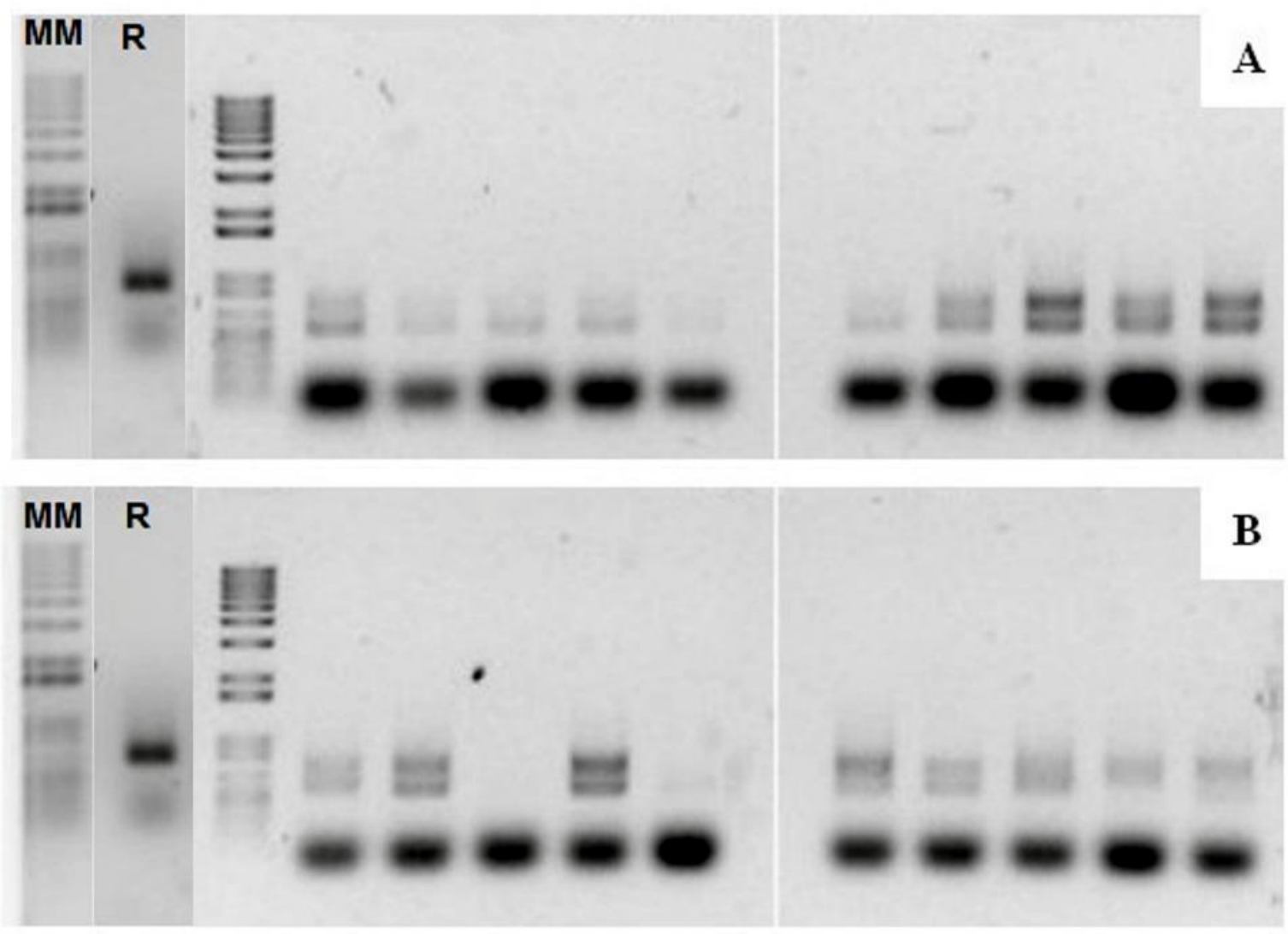

Figure 1. Banding patterns of yeast isolates and commercial strain PE-2 (R); molecular marker 1 $\mathrm{kb}(\mathrm{MM}) .1 \mathrm{~A}=$ samples from $05 / 03 / 2013$ and $05 / 28 / 2013 ; 1 \mathrm{~B}=$ samples from $06 / 29 / 2013$ and $10 / 10 / 2013$, utilizing primers $\mathrm{P} 1$ and $\mathrm{P} 2\left(54^{\circ} \mathrm{C}\right)$

In the PCR reaction utilizing the pair of primers $\mathrm{P} 3$ and $\mathrm{P} 4$ at $57^{\circ} \mathrm{C}$ for the samples from 05/03/2013 and 05/28/2013, the results obtained also show two distinct banding patterns as previously observed, however the bands seem to be more defined, allowing better observation of the diverging patterns (Figure 2a).

The samples from 06/29/2013 and 10/10/2013, analyzed under the same conditions, with the pair of primers $\mathrm{P} 3$ and $\mathrm{P} 4$ at $57^{\circ} \mathrm{C}$, once again demonstrate the same pattern of substitution of 
the commercial strain PE-2 by the indigenous varieties, as observed in the diverging banding pattern shown in Figure $2 b$.
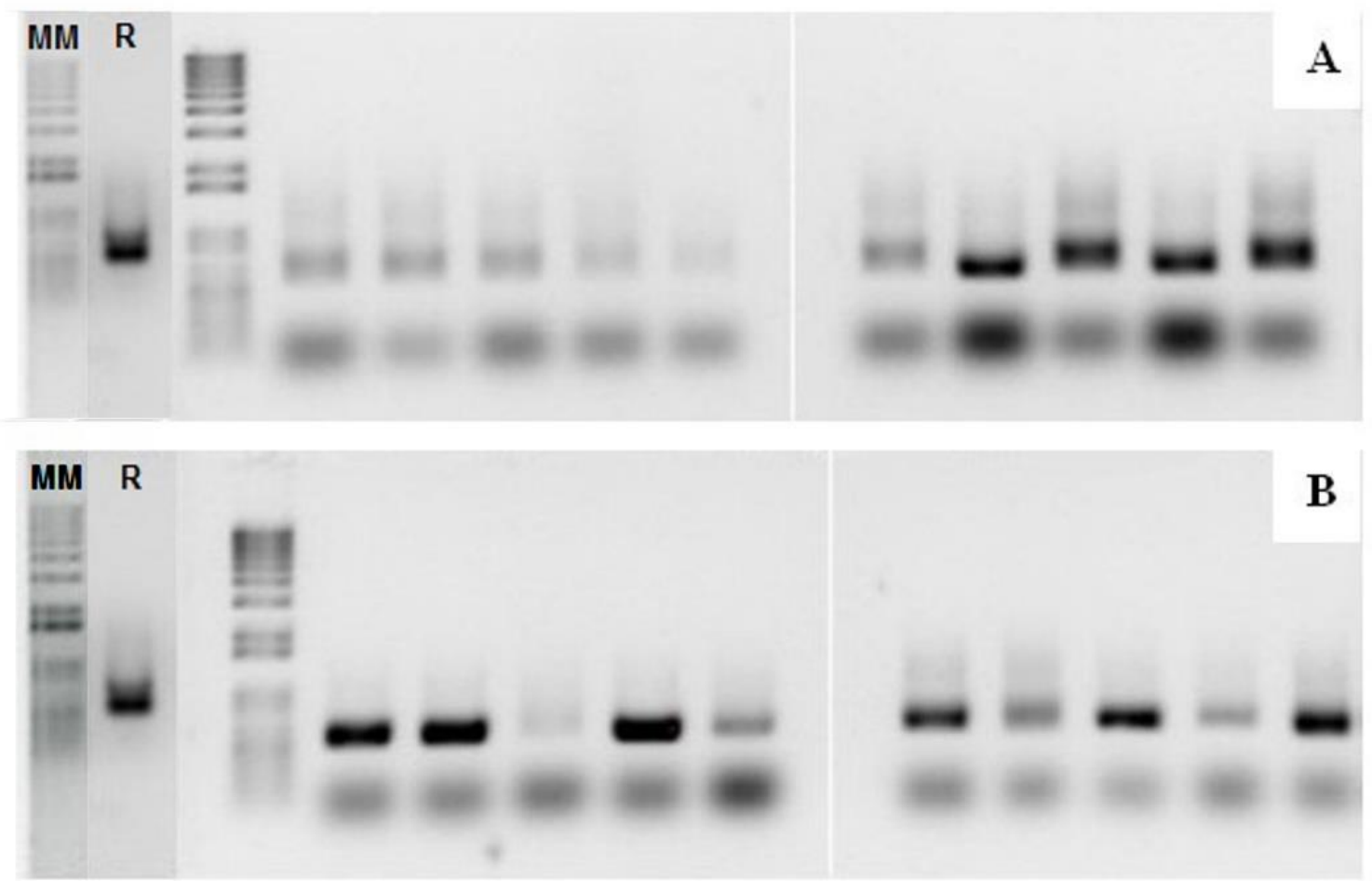

Figure 2. Banding patterns of yeast isolates and commercial strain PE-2 (R); molecular marker 1 $\mathrm{kb}(\mathrm{MM}) .1 \mathrm{~A}=$ samples from $05 / 03 / 2013$ and $05 / 28 / 2013 ; 1 \mathrm{~B}=$ samples from $06 / 29 / 2013$ and 10/10/2013, utilizing primers $\mathrm{P} 3$ and $\mathrm{P} 4\left(57^{\circ} \mathrm{C}\right)$.

The visual comparison of the banding patterns from the samples obtained since the beginning of sugarcane harvest season showed the dominance of an indigenous yeast strain, that proved to be better adapted in this specific fermentation environment than the commercial yeast strain PE-2.

It is worthy to mention that the main commercial yeasts strains used in Brazil's ethanol production are of indigenous origin, and were isolated as invaders with high productivity (CARVALHO-NETTO et al., 2013). It is not unusual that a more robust and well adapted indigenous strain out-competes and replaces starter strains, indicating that these indigenous strains can survive the stressful conditions found in the Brazilian fermentation process (RUYTERS et al., 2015).

Such observations suggest that the diversity found in the fermentation microbiota is correlated to the conditions to which they are exposed, which includes the raw material utilized in 
the production and the ethanol concentrations (REIS et al., 2018). Several studies show that these highly adapted indigenous strains that are brought into the process along with substrates are found in the surrounding environment or fermentation medium. The establishment and dominance of well adapted strains mainly occurs due to unique large-scale fed-batch process employed in Brazil, aided by the acid cell recycling that puts yeast cells under a great deal of stress (BEATO et al., 2016; CASTILLO et al., 2016).

Molecular characterization of isolated indigenous yeast benefits not only the ethanol producing industry, it is also a valuable technique for winemaking (TEODORESCU et al., 2019) and beer (LAUTERBACH et al., 2018; SANNINO et al., 2019), enabling the discovery of adapted strains with unique characteristics.

The dynamics of the microbial diversity in the Brazilian industrial process are still poorly understood and required systematic studies in order to understand the how the succession of yeast strains occur in the fermentation tanks (LOPES et al., 2016; SOUZA et al., 2018).

Despite the sanitization techniques employed by the ethanol producing units, and of the fermentative process, the results of this study show that, quite frequently, indigenous yeast strains will establish themselves in the process, being physiologically better suited to endure the stressing conditions.

This particular ethanol producing unit did not observe noticeable disturbances in the fermentation process, which leads to conclude that the particular indigenous yeast strains established possess desirable traits, comparable to the commercial strain employed at the beginning of fermentation. However, that is not the case for every contamination scenario, some ethanol producing units will experience decreased yield, high levels of flocculation and lower ethanol production.

\section{CONCLUSION}

We observed that the indigenous yeast strains isolated in this study are genetically distinct from the commercial strain employed in this particular ethanol producing unit. The molecular characterization utilized in this study is a reliable method to evaluate the yeast diversity found during the fermentation process, not only to ensure the stability of the process but also as valuable tool to identify yeast strains that possess desirable traits. 
These particular indigenous strains are possible candidates for use as starter cultures and further studies are needed to confirm its potential applications.

\section{REFERENCES}

AMORIM, H. V.; LOPES, M. L.; DE CASTRO OLIVEIRA; J. V., BUCKERIDGE, M. S.; \& GOLDMAN, G. H., 2011. Scientific challenges of bioethanol production in Brazil. Applied Microbiology and Biotechnology, Berlin, v. 91, p. 1267-1275. https://doi.org/10.1007/s00253-011-3437-6

BASSO, L. C.; DE AMORIM, H. V.; DE OLIVEIRA, A. J.; \& LOPES, M. L., 2008. Yeast selection for fuel ethanol production in Brazil. FEMS Yeast Research, Amsterdam, v.8, n.7, p. 1155-1163. https://doi.org/10.1111/j.1567-1364.2008.00428.x

BEATO, F. B.; BERGDAHL, B.. ROSA, C. A.; FORSTER, J.; \& GOMBERT, A. K., 2016. Physiology of Saccharomyces cerevisiae strains isolated from Brazilian biomes: new insights into biodiversity and industrial applications. FEMS Yeast Research, Amsterdam, v.16, n.7, https://doi.org/10.1093/femsyr/fow076

BONATELLI, M. L.; IENCZAK, J. L.; \& LABATE, C. A., 2019. Sugarcane must fed-batch fermentation by Saccharomyces cerevisiae: impact of sterilized and non-sterilized sugarcane must. Antonie van Leeuwenhoek, Amsterdam, v.1, n.11. https://doi.org/10.1007/s10482019-01250-2

CARVAlHO-NETTO, O. V.; CARAZZOLlE, M. F.; RODRIGUES, A.; BRAGANÇA, W. O.; COSTA, G. G. L.; ARGUESO, J. L.; \& PEREIRA, G. A. G., 2013. A simple and effective set of PCR-based molecular markers for the monitoring of the Saccharomyces cerevisiae cell population during bioethanol fermentation. Journal of Biotechnology, Amsterdam, n.168, n.4, p.701-709. https://doi.org/10.1016/j.jbiotec.2013.08.025

CASTILLO, J. A. V.; LAGUADO, J. A.; LÓPEZ, J.; \& GIL, N. J., 2016. New sources and methods to isolate vinasse-tolerant wild yeasts efficient in ethanol production. Annals of Microbiology, London, n.66, n.1, p.187-195. https://doi.org/10.1007/s13213-015-1095-0

DELLA-BIANCA, B. E.; \& GOMBERT, A. K., 2013. Stress tolerance and growth physiology of yeast strains from the Brazilian fuel ethanol industry. Antonie van Leeuwenhoek, Amsterdam, n.104, n.6, p.1083-1095. https://doi.org/10.1007/s10482-013-0030-2

LAUTERBACH, A.; WILDE, C.; BERTRAND, D.; BEHR, J.; VOGEL, R.F., 2018. Rating of the industrial application potential of yeast strains by molecular characterization. European Food Research and Technology, Berlin, v.244, p.1759-1772. https://doi.org/10.1007/s00217-0183088-2

LOPES, M.L.; PAULlILO, S.C.dL.; GODOY, A.; CHERUBIN, R.A.; LORENZI, M.S.; GIOMETTI, F.H.C.; BERNARDINO, C.D.; AMORIM NETO, H.B.; AMORIM, HV., 2018. Ethanol production in Brazil: a brigde between science and industry. Brazilian Journal of Microbiology, São Paulo, v.47, p.64-76. https://doi.org/10.1016/j.bjm.2016.10.003

MĄCZYŃSKA, J.; KRZYWONOS, M.; KUPCZYK, A.; TUCKI, K.; SIKORA, M.; PIŃKOWSKA, H.; WIELEWSKA, I., 2019. Production and use of biofuels for transport in Poland and Brazil - The case of bioethanol. Fuel, Amsterdam, n.241, p.989-996. https://doi.org/10.1016/J.FUEL.2018.12.116

VIANA, N.; PORTUGAL, C. B., \& CRUZ, S. H., 2017. Morphophysiological and molecular characterization of wild yeast isolates from industrial ethanol process. African Journal of Microbiology Research, Nairobi, v.11, n.37, p.1422-1430. 
https://doi.org/10.5897/AJMR2017.8691

REIS, V. R.; BASSI, A. P. G.. CERRI, B. C.; ALMEIDA, A. R.; CARVALHO, I. G. B.; BASTOS, R. G.;\& CECCATO-ANTONINI, S. R., 2018. Effects of feedstock and co-culture of Lactobacillus fermentum and wild Saccharomyces cerevisiae strain during fuel ethanol fermentation by the industrial yeast strain PE-2. AMB Express, Wien, n.8, n.1, p.23. https://doi.org/10.1186/s13568-018-0556-9

REIS, V. R.; BASSI, A. P. G.; SILVA, J. C. G. DA; \& CECCATO-ANTONINI, S. R., 2013. Characteristics of Saccharomyces cerevisiae yeasts exhibiting rough colonies and pseudohyphal morphology with respect to alcoholic fermentation. Brazilian Journal of Microbiology, São Paulo, v.44, n.4, p.1121-1131. https://doi.org/10.1590/S151783822014005000020

RUYTERS, S.; MUKHERJEE, V.; VERSTREPEN, K. J.; THEVELEIN, J. M.; WILLEMS, K. A.; \& LIEVENS, B., 2015. Assessing the potential of wild yeasts for bioethanol production. Journal of Industrial Microbiology \& Biotechnology, Houndmills, v.42, n.1, p.39-48. https://doi.org/10.1007/s10295-014-1544-y

SANNINO, C.; MEZZASOMA, A.; BUZZINI, P.; TURCHETTI, B., 2019. Non-conventional Yeasts for Producing Alternative Beers. Basic Research to Application, Springer, Cham, p.361-388. https://doi.org/10.1007/978-3-030-21110-3_11

STEENSELS, J.; \& VERSTREPEN, K. J., 2014. Taming Wild Yeast: Potential of Conventional and Nonconventional Yeasts in Industrial Fermentations. Annual Review of Microbiology, Palo Alto, v.68, n.1, p.61-80. https://doi.org/10.1146/annurev-micro-091213-113025

SOUZA, J.P.; PRADO, C.D.; ELEUTHERIO, E.C.A.; BONATTO, D.; MALAVAZI, I.; CUNHA, A.F., 2018. Improvement of Brazilian ethanol production - Challenges and perspectives on the identification and genetic modification of new strains of Saccharomyces cerevisiae yeasts isolated during ethanol process. Fungal Biology, Amsterdam, v.122, p.583-591. https://doi.org/10.1016/j.funbio.2017.12.006

TEODORESCU, R.I.; BARBULESCO, D.I.; TUDOR, V.; MARIN, S.M., DUMITRACHE, C.; FRINCU, M.; DIGUTA, C.F.; MATEI, F., 2019. Molecular characterisation of new yeast strains isolated from grape marc in Pietroasa Winemaking Centre, Romania. Journal of Biotechnology, Amsterdam, v.305, $\quad$ Supplement, $\quad$ p. $\quad$ S53. https://doi.org/10.1016/j.jbiotec.2019.05.187

XUFRE, A.; ALBERGARIA, H.; GÍRIO, F.; \& SPENCER-MARTINS, I., 2011. Use of interdelta polymorphisms of Saccharomyces cerevisiae strains to monitor population evolution during wine fermentation. Journal of Industrial Microbiology and Biotechnology, Houndmills, v.38, n.1, p.127-132. https://doi.org/10.1007/s10295-010-0837-z 